\title{
Téoros
}

Revue de recherche en tourisme

\section{Changing Quebec City in Changing Travel Guide Books}

\section{Jan O. Lundgren}

Volume 12, numéro 1, mars 1993

Québec, capitale et région touristiques

URI : https://id.erudit.org/iderudit/1078196ar

DOI : https://doi.org/10.7202/1078196ar

Aller au sommaire du numéro

Éditeur(s)

Université du Québec à Montréal

ISSN

0712-8657 (imprimé)

1923-2705 (numérique)

Découvrir la revue

Citer cet article

Lundgren, J. O. (1993). Changing Quebec City in Changing Travel Guide Books. Téoros, 12(1), 13-17. https://doi.org/10.7202/1078196ar d'utilisation que vous pouvez consulter en ligne.

https://apropos.erudit.org/fr/usagers/politique-dutilisation/ 


\title{
Changing Quebec City in Changing Travel Guide Books
}

\author{
Jan O. Lundgren*
}

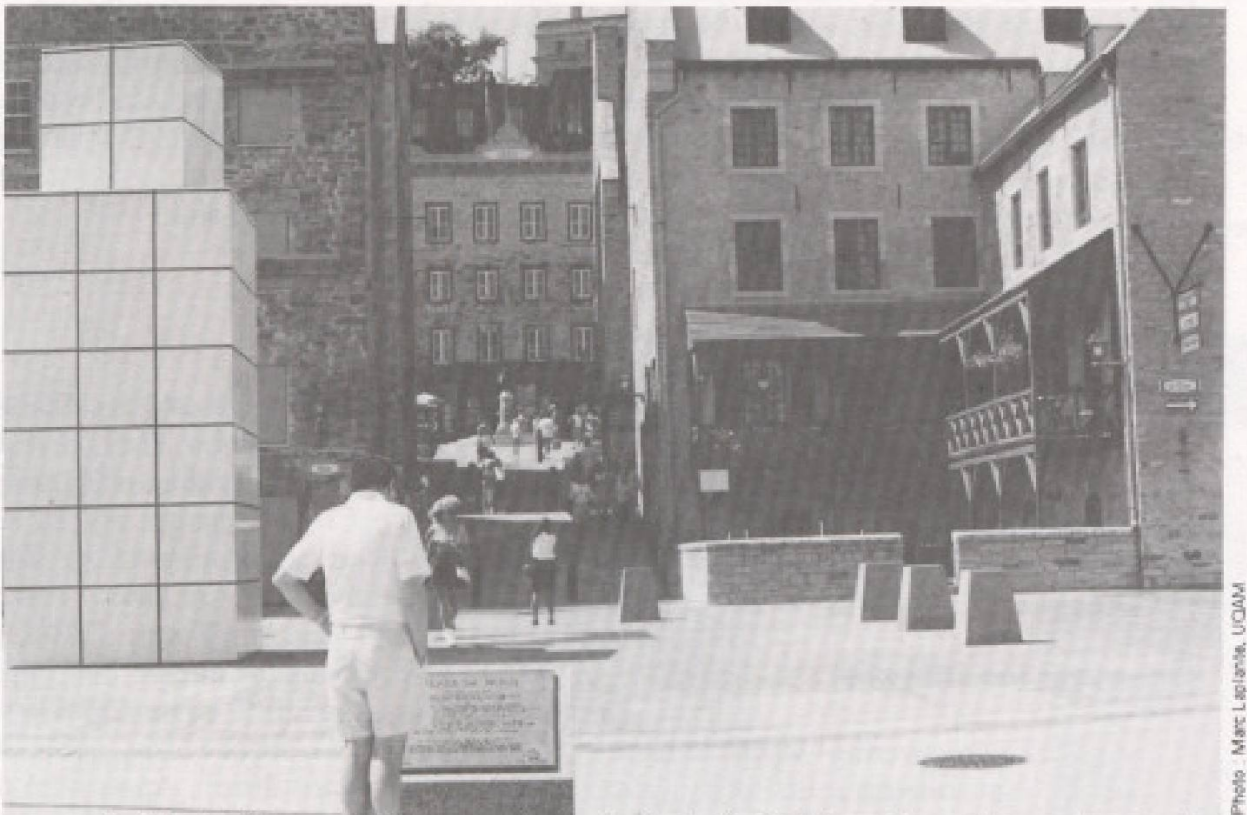

*.. Hew atractions that become local fixtures or landnanks in a destination through human intervention, may also emerge.s.

\section{Purpose: the study of an information process}

Guide books, be they of the older travel account version or of the modern, more systematic information kit type share a common characteristic in design and format: they must be information selective. For practical reasons they must limit the information provided to matters deemed relevant to the tourist visitor. Therefore, they tend to highlight certain features - notably tourist attractions - about the destination. In older versions this information filtering and the final information result often reflected the occupational/professional background of the author and/or his personal, subjective interests. Not only has the format and the structure of the guide books changed as tourist travel has transformed during the past 100 years or so, but so has also the authorship. Before 1914 most guide books were written by individuals. Thus Karl Baedeker of Leipzig, whose various guide books introduced the modem systematic guide book format, although he

Mr. Jan O. Lundgren is professor, Department of Gecgraphy, MoGill Uniwersity, Montreal. did not write the book himself, at leastclosely supervised and edited the works. As the Preface to Baedeker's Norway and Sweden (1892) states: «... Like the Editor's other handbooks it is based on personal acquaintance with the country described, the chief places in which he has visited repeatedly. His efforts to secure accuracy and completeness... have been supplemented by the kind assistance of several gentlemen. Norwegian, Swedish, Danish, English and Ger$\operatorname{man}_{. . .} x(1)$

Over time the travel guide books have become, increasingly, team work products, as witnessed in the recently published Michelin Quebec Touring Guide ${ }^{(2)}$. A final, but critical consideration in assessing guide books is related to the geographic origin of the authorship. Both earlier versions of guide books and more recent publications have been written and published by people visiting the destination. Thus, even the most popular contemporary guides have been prepared by persons that invariably view the destination from the perspective of a visitor, albeit a very knowledgeable outsider. To some degree this is an advantage to future users of the guides - the author may be in a better position to appreciate and anticipate the problems encountered by the tourists during a stay due to his affinity with the visitor.

In this study, we will investigate guide books that have their authorship from outside the destination, i.e. in distant regions or cities that generate the tourist travelers. This is a clear limitation in the investigative design. However, had we chosen the alternative approach we would have produced a very different study - interesting no doubt, but also much more complicated to execute.

\section{Guide books on Quebec City and its environs}

The main objective of this exercise is to compare a set of guide books for Quebec City and its environs. The more specific task is to establish to what extent, over time, the presentation of the destination in general - the Quebec City information package, with its various attributes - has changed. Clearly, as the type of tourists visiting Quebec City has changed during the past hundred years or so, the aid by which most tourists negotiate themselves through ( $=$ consume) their destination environment should see substantial changes as well. The above does not necessarily mean that the guide books have been revolutionized in terms of content. Certain parts of a guide book obviously remain the same over the years, simply due to the fact that tourist destinations, invariably, are made up of certain, location-wise, permanent features and principal attractions. Thus, travel guidebooks retain these elements, while for others regular revisions are made, simply because the information quickly becomes outdated, especially for such items as prices on services or local transport. But new attractions that become local fixtures or landmarks in a destination through human intervention, may also emerge. For Quebec City and its environs such city-locared areas as Vieux Port, Ville Basse and Plains of Abraham are, in a sense, enhanced additions to the roster of already existing, older attractions features as can also be the case with programmed events - the Carnaval or the Tallships - to mention some. 


\section{The Model Guide book}

From the above we can conceptualize the information process and the information content of the typical tourist guide - producing a model guide against which we can compare and assess guidebooks published during different eras. Basically, a guide book tries to inform the traveler about three broad categories of information (see fig.). The basic component incorporates the formative, principal features of the destination, which would include elements of the broader physical and cultural-historical landscape, features that are geographical fixtures and in many respects sets the stage for the destination. Thus, in Quebec City the prominence of the site - the rock with the impressive river belowemptying into the Gulf of St. Lawrence, the two distinct elevations of the urban landscape with its Vieux Quebec on the Ville Haute level and low lying Ville Basse at the base of the rock represent outstanding characteristics that belong to the basic category. To this could also be added certain well recognizedand quite visual historiclandmarks such as the Citadel, the Plains of Abraham and the Chateau Frontenac silhouette. If we were to compare Quebec with Montreal we discover, similarly, distinct elements belonging to the same basic component, notably the two mountains - Mount Royal and its park in particular. Such basic elements tend to give the destination its visual profile, its general place character. The second component adds on attraction elements to the destination. These add-ons are often manmade modifications of physical or distinct cultural landscape features; for instance, the galaxy of stations de ski in Quebec City environs falls into this category. It would be hard to envisage a contemporary Quebec City guide book not referring to places such as MontSt. Anne, Stoneham orLac Beauport, all part of the easily accessible Quebec City recreational hinterland ${ }^{(3)}$, also frequented by tourists. These attractions have become importantattractions not just by being part of the Quebec City region's tourist resource make-up and marketing image, but they are, indeed, also attractions that can survive in a competitive marketplace in their own right! Likewise, the rehabilitated sites of the Ville Basse and Vieux Port districts have also added on notable elements in the attraction mix of the city in the same way as in Montreal the renovated the Vieux Port and St. Helen's Island have become important additions to Montreal's system of attractions. The third component - tourist services - represents the more practical side of tourist visitations toan area: accommodation, restaurants, transport services, entertainment, shopping, opening and closing hours for business, post offices, museums, price information on taxis and local transport services, etc. These types of information represent a variable component in the guide book information package simply because they require constant updating. In the eyes of the tourist visitors the third component information is crucial because it contains vital operational information, critical for both planning and execution of the visit to the area. From the perspective of the visitor's appreciation of the placecharacter of the destination, the third component matters perhaps less. The basic information and the added on information represent in many respects the true touristical sets of information. These elements have most likely brought the destination to the attention of the potential visitor in the first place, while the elements of the variable component may explain how the visitor will operationalize his intended visit.

\section{Selection for analysis}

Early guide books covering Quebec go back quite far ${ }^{(4)}$. Nevertheless it first is with the opening of the Victoria railway bridge, that tourism really starts to expand, and more guide books are produced ${ }^{(5)}$ giving Hunter's Panoramic Guide increasing competition. The first guide catering specifically to the modern tourist - the motorist - was published 50 years later, around $1917^{(7)}$.

Given that we want to see the extent to which guide books informing about Quebec city and its environs have changed their format and content over time the choice must be made in a historical context that reflects the history of tourism travel in the Quebecregion. Thus, the first guide book to be analyzed reflects the earliest era of modem tourism, i.e. that of the late 19th century railway travel, which in Canadastarts around $1850(7)$.

Similarly, a principally new trend in tourist travelcan beidentified in the interwarera,esp. starting in the $1920^{\prime}$ 's with the arrival of the Northamerican automobile tourist on the scene. The choice of guide for our analysis - the 1922 edition of Baedeker's Canada-fits well into the era and also provides a good contrast to the earlier 1907 - version from the same publishing house.

The final choice reflects the most recent era of tourist travel in Quebec, when air traveling as well as motoring are popular transport modes both to and within Quebec. We have chosen the 1992 Michelin Quebec Touring Guide as being a good modern example.

Apart from scrutinizing the guide books per se, reference will also be made to other types ofQuebecCity tourist information, especially material produced by the railway corporations, notably the Canadian Pacific. The C.P. became a major stakeholder in Quebec City with the opening of its Chateau Frontenac (Hotel) in 1883. Thus, the C.P. actively started to promote the city and its environs at an early stage - and still does.

\section{The 1870 's guide}

All the guide books selected for analysis have one thing in common: they are really Canadianorprovincial-orientedpublications, in which the City of Quebec and its surroundings occur as a sub-section. Thus, Appleton's Handbook of American Travel Northern and Eastern Tours (1873), an impressive volume of almost $\mathbf{3 0 0}$ pages, devotes less than $10 \%$ of its pages to the British provinces, out of which Quebec City is given a niggard three! Apart from describing the most convenient railway links the Grand Trunk lines from New England and the C.P. Southshore/Northshore links with Montreal the guide consists basically of a listing of the distinct urban quarters in the City-from the citadel at the top via the walled Upper and Lower Towns to the details of sites to see. The tourist's Quebec is geographically quite circumscribed and none of D. Thoreau's enthusiastic exclamation that *... the view from Cape Diamond has been compared with the most remarkable views of a similar kind in Europe, such as from Edinburgh Castle, Gibraltar, Cintraandothers and preferred by many $x^{(0)}$ is aired by the Appleton account of Quebec. What is said is said with very littleenthusiasm and represents mostly a listing of places to see, with little background information. The tourist's discovery space is limited to the walled town space, to which has been added some excursions beyond the Plains of Abraham, Wolfe's Coveand the Chaudiere Falls. In the more inaccessible environs reference is made to the Montmorency Falls, as well as those of St. Anne. No reference is made to St. Anne de Beaupre or for that matter the old-world environment of Ile d'Orleans. One gets an impression of visitor claustrophobia. Even if Quebec City is a much smaller place than today, it is surprising that the guide does not indicate the convenient opportunities that 
exist to use Quebec City as a base of operation for forays out on the Gulf of St. Lawrence. Elsewhere in the book reference is made to thecoast, but this is not functionally integrated into a convenient tourist travel movement.

Further, one has notdiscovered the usefulness of a place map for orientation purposes and the visitor is given noadvice on the geographic dimensions he is facing. Thus, he starts with a blank space that he has to fill up through his own initiative - indeed a joumey into the unknown! Of the basic elements of the Model Guide we can conclude that there is a modest but extremely basic account of the site landscape, but with little accentuation. There is no evaluation of the significance of manmade attractions listed, perhaps with some exception for names and buildings associated with the British colonial history the citadel, the battlefield, the Durham Terrace, the Artillery Barracks. No order of priority of visitations among the 20 odd principal attractions is recommended. For the operating tourist the guide has limited value.

\section{Turn-of-the-century to Pre World War I days}

The 1907 Baedeker's Canada ${ }^{(9)}$, a massive volume of over 300 pages, represents a new approach in providing tourists with information on a destination. Karl Baedeker of Leipzig had honed his guide book writer skills on numerous city and country volumes before taking on North America. Already in 1876 , his guide book covered exotic countries, especially with the publication of Palestine and Syria - with 18 maps, 43 plans, a panorama of Jerusalem and 10 views. In the 90's he concentrated on Europe, from Southern Italy and the Mediterranean (1890) to Norway-Sweden in the North (1892). The Dominion of Canada (1907) volume with over 300 pages allocated $15-16$ pages each to Montreal and Quebec City.

Baedeker may not have been the first guide book author to introduce professional cartography to go with the text, but his guides excelled in accurate mapping of both destination regions and urban areas ${ }^{(10)}$. The maps were/are standardized in style, symbols and usually in a geographic scale that makes them highly useful. For Quebec, the whole built-up area is covered, showing street layout, street names, important areas, public buildings and even monuments. The tourist is provided with an effective tool for inde- pendent exploration of the destination. All three components - from the basic to the variable are used to portray the town.

Baedeker is very systematic; his isa structured approach to information, but does still include more subjective descriptions, often in the form of citations from earlier visitors. There is emphasis on important sites. Thus, Quebec' is referred to as being $\alpha_{\text {a. }}$ superbly located...., $*, .$. most picturesque in North America... $\%, \alpha_{\ldots .}$ striking boldness of site...., «The streets as a rule are narrow and irregular... quaint houses..., ${ }^{\text {. Th }}$. This is then followed by a more detailed, but historically more elaborate presentation of places to visit, and it concludes, in modern fashion, by identifying the principal shopping streets, among them St. Joseph, St. Jean andFabrique. But the view seems to be the dominant - and rightly so, from Dufferin Terrace and the Citadel. Compared with the guides of the previous century one can talk about a truly liberated tourist: with the Baedeker in hand, he explores the destination most on his own!

\section{The interwar era - the 20's}

The 20 's is indeed a new era in more than one way. The vestiges of the Old Order were sharply reduced, if not completely swept aside. The casualties of WWI had hit hard, not simply in the form of thinning the ranks of the ruling class, here defined in its broadest sense, but also bringing about new mores, new attitudes and also new forms of leisure and recreation - including travel. Even if truly mass participation in leisure and recreation pursuits had to wait until a second global convulsion was over, it is still fair to say that the traditional ways of pursuing tourist travel was passe - a consequence very much of the automobile. The dependency upon railway travel was still strong but an increasing number of travelers demonstrated a different spatial mobility through private car ownership, with considerable consequence for the shaping of tourism geography.

For Quebec the railway still dominated the travel experience, as witnessed in the development even of tourist areas relatively close to major, travel generating urban centers, as was the case both with the Montreal Laurentians, the Lake Memphremagog resort area and the functioning of tourism along the shores of the Gulf of St. Lawrence. The railways combined with hotel ownership, as in the case of the C.P. and Quebec City, which was reflected in the promotional campaign of the two functions combined.
Indeed, judging from the C.P.'s public relations material, it was C.P. ${ }^{(11)}$ that introduced the commercial link between fine urban lodging (at the Chateau Frontenac) and great outdoors experience (in the form of sleighing and skiing through an unspoiled, serene winter landscape). The same company sometimes provided eloquent presentations on Quebec City, that captured both basic elements and spirit of place: $\alpha_{\ldots, .}$ uphill and downhill it goes, this old city of Quebec, with a Gallic abandon and the unexpected... meeting you around the corner. Its habitants will tell you their city is the most beautiful in the world... with that assurance that comes from... complicit belief. Perched on Cap Diamond, over which it spreads... a commanding and superb view of the St. Lawrence, its claim to be one of the most picturesque of cities will be contested by nones ${ }^{(12)}$. Statements like this are indeed difficult to surpass.

The 1992 edition of Baedeker's Canada handbook $^{(13)}$ has grown since 1907 to over 400 pages. The number of pages covering QuebecCity has notchanged, which suggests that the content, likewise, has remained unchanged. The map format remains, although some peripheral urban developments indicated. The textstresses the wstriking boldness of its site, the romance of its history and the extraordinary contrast of its old world appearance and population with the new world around its ${ }^{(14)}$. A more practical sequencing of how to experience the city's altractions seems to have been introduced. Thus, the visitor is taking on a tour d'horizon starting at the Dufferin Terrace and the citadel in ever-widening loops through most of the Upper Town within the walls. Beyond the walls are included the mandatory visits to the impressive Parliement Buildings, to the Plains of Abraham, and Wolfe's monument. The Lower Town gets limited treatment - The Harbour basin and the Notre Dame des Victories Church. As far as excursions go, Levis, Montmorency Falls and Ile d'Orleans seem to qualify. Little new has been added and there is again a poor link with the broader surroundings so conveniently accessible through day excursions from the city. Quebec is treated rather as a point and a place with little reference toitspotentialas an operational base for the visitor. The comment on the $\alpha_{a .}$ comparatively uneventful... history» ${ }^{(15)}$ since $1775-76$ is something of a misnomer for the considerable development during the 19th century. To conclude, one gets the general impression that the 1922 Baedeker rests on old laurels with less than a sincere effort to truly update the format. Or, rather, perhaps 
the Baodeker publishers believed that they had found the ultimate format the effort to modify was limited. And perhaps, indeed, little had happened in Quebec since 1907.

\section{The contemporary decades - post 1945}

A number of travel guides were published in the postwar decades, among them the famous GuideBleues Au Québec ${ }^{(16}$ and the Michelin Guide combining Canada and New England in $1982^{177}$. However, the mostcontemporary approach to a tourist"s visit to Quebec comes in the 1992 Michelin Touring Guide for Quebec $^{\text {(1) }}$, published in May 1992, which here is used as a representative sample, both in terms of its novelty, but also as a result of its guide book format. Its 276 pages - 26 for Quebec (l) - come in a most carefully structured information package for the province as a whole and with a detailed listing of places and sights to see, both in urban, rural and regional settings.

The Michelin Guide handles the essential cartography with systematic panache: effective scale applications take the visitor into the area by way of a broad overview map that covers the whole of the region - from the airport in the west to Montmorency Falls in the east - and both shores of the river; the Upper and Lower Town district maps have the same scale, the coloration used differentiates principal land uses well, and map symbols, finally, are easy to comprehend - if the reader cares to check the Organization of the guide - the back page of the book's front cover. The content is impressive with over 100 specificentries, identifying specificsites, buildings and historically significant areas of the city, with detailed historical explanation to each one. In a sense the material is overwhelming at first glance. The Michelin guides have gone one step further in terms of assisting the tourist's discovery process: a number of walking tours have been identified and have been clearly marked out on large scale maps. The tours take the visitor through the Lower and Upper Towns in a systematic manner, describing the various sites, and sights. The guideeven suggests approximate walking time, which makes for better overall time planning of the stay in the city.

The Michelin guide is detailed to the point of makingitanencyclopedia. Froman efficiency point of view the walking tours screen out the detailed information and places it all into a sequential context. What perhaps is lacking

\section{COMPOSANTES D'INFORMATIONS TOURISTIQUES DE LA VILLE}

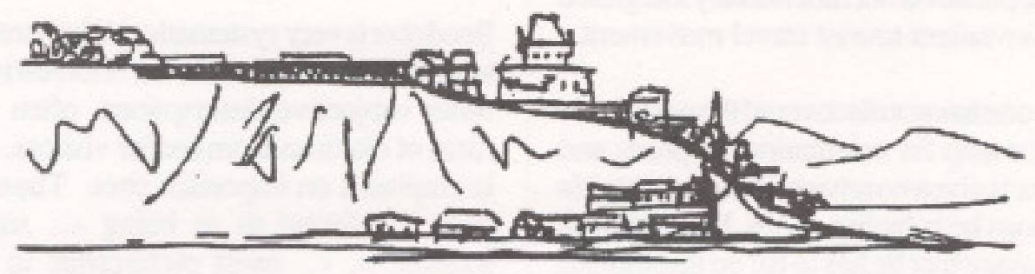

VARIABLES

- Services générales

- Services d'informations

- Transports locales

- Restaurants

- Logements

ADDITIONELS : $\quad$ Sites mobilisćes

- Institutions principales

- Endroits historiques renovés

Composantes principales d'informations
- Occupation humaine

- Topographie

- G6́omorphologie

- Location générale is a suggestion as to what would be the best way of getting a feel for the City, which brings us back to the question of the principal components: the basic, the additions and the variable. To get a sense of place one can argue that the visitor may benefit from getting firstanoverview, then the details. Quebec, and the same applies for Montreal, provides such an opportunity due to the site, a fact that is never stressed to the visitor. Thus, the geographic panoramas from the lookouts should have been stressed as starting points for the discovery process! After that experience, the guide can direct the visitor to the specifics - the walking tours and to other attractions.

\section{Conclusions}

Tourist guide book plays an importantrole in the tourist's discovery of a destination. On one hand they can assist in the portrayal of the destination and can therefore influence the visitor's perception and image of the area. They must also demonstrate considerable factual accuracy that relates to the place character of the destination, but can, nevertheless, through the image conveyed by the author style of presentation also assist the tourist in formulating his preconceived notion of what the place he intends to visit might be like. Therefore, guide book writings matter 
to destination areas that wish to maintain their appeal, or enhance their attractivity.

The guide books used in this essay represent a small sample indeed. The list could easily have been expanded. However, the purpose was simply to demonstrate the manner in which, over the pastapproximately 100 years, the presentation and format of guide book contents dealing with Quebec City have changed. As a result, the modern guide books represent information kits that inmany respects provides the traveler with a more functional, accurate and precise tool to apply to what still makes tourist travel tick, the process of discovery - the guts of true tourism. 7

\section{REFERENCES}

(1) BAEDEKEA, Karl. Baedeker's Norway and Sweden, Leipzig, Germany, 1892.

(2) MICHELIN TIRES CANADA LTD. Michelin Que bec Touring Guide, Dorval, Quebec, 1992, 276 p.

(3) MINISTERE DU TOURISME, The Greater Cuebec Area Guide, Gouvernement du Québec, Quebec, 1992, $160 \mathrm{p}$.

(4) PELLETIER, J. La belle province comme on $\mathrm{fa}$ presente $d$ hiler 4 sujourdhui, Thoros, no 2. Montréal, juin 1982, pp. 2-7.

(5) J.P. JEWEIT AND CO., Hunter V.S.: Hunter's Panoramic Guide from Niagara to Quebec. Cleveland, Ohio, 1857, $66 \mathrm{p}$.

(6) Tóoros, ibid.

17) APPLETON, D. AND COMPANY, Appleton'a Handbook of Amorican Travel - Northern and Eastern Tours, New York, 1873, 294 p.

(B) Toros, ibid.

(9) BAEDEKER, Karl, Baedeker'a Canada, Leipzig. Germany, 1907, 331 p. Quebes: pp. 145-160.

(10) CHUBB, M., One Third of Our Time, 1981.

(11) CANADIAN PACIFIC CORPORATE ARCHIVES, Chateau FrontenacHotelBrochure File, Windsor Station, Montreal.

(12) CANADIAN PACIFIC CORPOAATE ARCHIVES, Travel Gulde to Quebec and the Maritimes, Windsor Station, Montreal, 1934.

(13) BAEDEKER, Karl, Baedeker's Canada, Leipzig. Germany, $1922,420 p$.

(14) Ibid.

(15) lbid.

[16] GUIDES BLEUS, Au Ouebec, N.M.I.L., Montréal, 1976.

(17) Michelin Quobec Touring Guide, ibid, 1992.

(18) lbid.

The author is indebted to the Canadian $\mathrm{Pa}$ cific Corporate Archives at Windsor Station, Montreal for providing the opportunity to consult the special documentation files on Chateau Frontenacand the Quebec City area. The pamphlet material in these files have provided interesting examples on travel promotion relative to the Quebec City region, where in 1993 the company will celebrate the 100 th anniversery of the opening of one of the most prestigious hotel operations in the $\mathrm{CP}$ hotel and resort chain.

\section{DÉJÀ PARUS DANS LA COLLECTION COLLOQUES ET CONGRÈS DES ÉDITIONS TÉOROS}

No 1:

Les politiques touristiques (34 pages)

Actes du colloque organisé par la revue Téoros dans le cadre du Congrès annuel de I'Association canadienne-francaise pour l'avancement des sciences (ACFAS), tenu à Sherbrooke en mai 1991. Ce premier numéro rassemble des textes de André Coupet, Jacques Demers, Louis Jolin, Roger Nadeau et Jean Stafford. Le conférencier invité, le professeur Bernard Morucci, est directeur du Centre d'études supérieures du tourisme de I'Université de Paris I. Panthéon-Sorbonne; il est souvent soll icité à travers le monde pour diriger des séminaires intensifs sur la planificatin du développement du tourisme.

\section{No 3: \\ Colloque international \\ Fleuves et planète (52 pages)}

Un colloque international intitulé Fleuves et Planète s'est tenu à Montréal en octobre 1992. La SODES (Société de développement économique du Saint-Laurent), I'UQAM, et particulièrement ses instances spécialisées en tourisme et le Centre SaintLaurent d'Environnement Canada ont uni leurs efforts pour rassembler au Québec plus de 200 spécialistes des fleuves et de leur importance dans l'économie et la culture des pays. L'événement s'est tenu sous la présidence de M. Pierre-Marc Johnson et a reçu le parrainage de très nombreux acteurs influents de Montréal, du Québec et du Canada, y compris de l'Organisation mondiale du tourisme.

Ce numéro de COLLOQUES ET CONGRÈs complète le contenu du numéro régulier de Téoros de l'automne 1992 (vol. 11, no 3) sur le même thème, numéro distribué à toutes les personnes présentes au colloque.

\section{No 2: \\ Le tourisme de circuit (44 pages)}

Ce document constitue les actes du premier colloque national sur ce sujet, organisé par l'Association touristique ChaudièreAppalaches et tenu à Saint-Georges de Beauce en avril 1992. Sur ce theme pourtant stratégique pour le développement du tourisme, la quasi totalité des 11 interventions reproduites dans les actes de ce colloque sont des "premieres". De toute évidence, la rencontre a eu lieu entre chercheurs et praticiens et il semble bien que cette publication fera date puisqu'elle est régulièrement demandée. L'accueil et la logistique ont reçu l'aide du Collège Mérici (techniques de tourisme), de ses professeurs et étudiants. Les gouvernements du Québec et du Canada ont été des partenaires de l'événement.

\section{No 4: \\ L'écotourisme (48 pages)}

Ce quatrième numero de la collection rend compte des communications et des discussions du colloque national sur ce sujet, tenu à Pohénégamook, du 3 au 6 novembre 1992. Les échanges ont été vifs, francs et ont souvent apporté des regards neufs sur un sujet pourtant assez nouveau en luimême. La vingtaine de textes de ce numéro témoignent bien que l'écotourisme est un concept pertinent aujourd'hui. La réalisation de l'événement fut une initiative conjointe de l'Association touristique du BasSaint-Laurent, de Pohenégamook SantéPlein Air et de l'institut de plein-aip québécois, aidés de plusieurs partenaires et commanditaires.

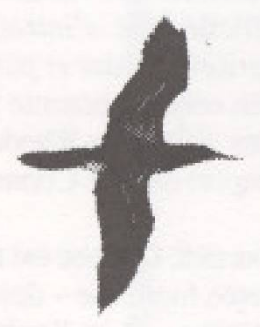

\section{À PARAîTRE (mai 1993)}

No 5 : Tourisme et culture. Une alliance d'avenir?

Colloque du Musée de la Civilisation de Québec, avec la collaboration des Associations touristiques régionales associees du Quebec (ATRAQ), de l'UQAM et du journal Le Devoir. 